Volume 5 Issue 3, November 2021

sisaddergi@gmail.com

Makale Türü/Article Type: Araştırma/Research

Makale Gönderim Tarihi/Received Date: 07.09.2021

Makale Kabul Tarihi/Accepted Date: 24.09.2021

DOI: $10.30692 /$ sisad.992529

\title{
REPRESENTATIVE DEMOCRACY AND THE CONCEPT OF REPRESENTATION: DO THEY HAVE A LEGITIMIZING OR CHECKING FUNCTION?
}

\section{Temsili Demokrasi ve Temsil Kavramı: Meşrulaş̧ırıcı mı Yoksa Kontrol Edici Bir İşleve mi Sahip?}

Yavuz Selim ALKAN

Dr. $\ddot{O} \breve{g} r . \ddot{U} y e s i$

Akdeniz Üniversitesi

Iktisadi ve İdari Bilimler Fakültesi

Siyaset Bilimi ve Kamu Yönetimi Bölümü

ORCID ID: 0000-0002-5211-5809

yavuzselimalkan@akdeniz.edu.tr

Atuf/Citation: Yavuz Selim Alkan, (2021), "Representative Democracy and the Concept of Representation: Do They Have A Legitimizing or Checking Function?”, Stratejik ve Sosyal Araştırmalar Dergisi, C.5, S.3 Kasım 2021 s.441453.

\begin{abstract}
The notion of representative democracy has been an influential and relatively dominant understanding of democracy throughout the twentieth century. A growing body of scholarly literature has therefore emerged focusing on representative democracy, its institutions, and the following decision-making procedures: elections, voting, and the roles and functions of representatives. Given especially the functions of representative democracy, Jonathan R. Macey raises a crucial question of whether democracy should "serve either to legitimize or to check government". This study aims to answer this question by examining both the concept of representation and the oft-cited definitions and understandings of representative democracy in the scholarly literature. This examination is undertaken with the perspective that democracy has normative and institutional dimensions: there may be disagreement over the value of particular institutional arrangements to serve democracy, however, there is a consensus over the essential normative principles/values and some institutional requirements of democracy. As a result of the examination, it has been revealed that some oft-cited perspectives on the concept of representation and representative democracy agree on democracy's legitimizing function, but they disagree on accountability or responsiveness of representatives or the minimum conditions of representative democracy. In other words, even though those perspectives share some core checking mechanisms, conflict becomes much more obvious when it comes to envisioning more substantive values or institutional mechanisms. This is mainly because while the legitimizing function of democracy stands as a more neutral attribution embedded in and can be shared by any understanding of (representative) democracy, the checking function has a liberal content with a normative quality.
\end{abstract}

Keywords: History of political thought, representation, representative democracy, liberalism. 
Özet: Temsili demokrasi düşüncesi, yirminci yüzyıl boyunca etkili ve nispeten baskın bir demokrasi anlayışı olmuştur. $\mathrm{Bu}$ nedenle; temsili demokrasi, onun kurumları ve şu karar alma prosedürlerine odaklanan ve giderek gelișen bir akademik literatür oluşmuştur: seçimler, oy verme ve temsilcilerin rolleri ve işlevleri. Özellikle temsili demokrasinin işlevleri ele alındında, Jonathan Macey, demokrasinin "hükümeti meşrulaştırmaya mı yoksa denetlemeye mi" hizmet etmesi gerektiği konusunda hayati bir soru sorar. Bu çalışma hem temsil kavramını hem de akademik literatürde sıklıkla atıf yapılan temsili demokrasi tanım ve anlayışlarını inceleyerek bu soruya yanıt vermeyi amaçlamaktadır. Bu inceleme, demokrasinin normatif ve kurumsal olmak üzere iki boyutu olduğu bakış açısıyla yapılmıştır: Demokrasiye hizmet edecek belirli kurumsal düzenlemelerin değeri konusunda anlaşmazlık olabilir, ancak demokrasinin temel normatif ilkeleri/değerleri ve bazı kurumsal gereklilikleri üzerinde bir fikir birliği vardır. İnceleme sonucunda, sıkça atıfta bulunulan temsil ve temsili demokrasi kavramına yönelik bazı yaklaşımların demokrasinin meşrulaştırıcı işlevi üzerinde anlaştıkları, ancak temsilcilerin hesap/yanıt verebilirliği veya temsili demokrasinin asgari koşulları konusunda ihtilafa düştükleri ortaya konmuştur. Başka bir deyişle, bu yaklaşımlar bazı ortak temel kontrol mekanizmalarını paylaşsa da, konu daha önemli değerler veya kurumsal mekanizmaları formüle etmeye geldiğinde çatışma çok daha belirginleşmektedir. Bunun nedeni, demokrasinin meşrulaştırıcı işlevi, herhangi bir (temsili) demokrasi anlayışında yerleşik olarak bulunabilecek ve bu anlayışlar tarafından ortak olarak paylaşılabilcek tarafsız bir niteliğe sahipken, denetleme işlevi daha çok normatif niteliğe sahip liberal bir içerik taşımaktadır.

Anahtar Kelimeler: Siyasal düşünce tarihi, temsil, temsili demokrasi, liberalizm.

\section{INTRODUCTION: TWO DIMENSIONS OF DEMOCRACY}

Democracy has been defined in different ways by a great number of scholars. Even though a generally accepted definition of democracy has been sought to formulate, those who attempted have been "constantly refuted" (Gagnon, 2010, p. 5). Accordingly, the scholarly literature is replete with a great variety of opposing definitions and understandings of democracy even though all of them address the same question: What is democracy? (see, Kelsen, 1955; Pickles, 1970; Diamond, 1990; Schmitter and Karl, 1991; Paul et.al., 2000; Crick, 2002; Saward, 2002; Held, 2006; Ringen, 2007; Weale, 2007; Ober, 2008; Anderson and Stephenson, 2020; Collins, et. al. 2020).

Dorothy Pickles (1970, p. 9) regards this question as one of the most thorny questions to answer. Even it is unusual to find a word like democracy which has several divergent meanings at the same time (Roskin et. al., 2003, p. 73) and is said to mean both "all things to all people" (de Schweinitz, 1964, s. 13) and "different things to different people" (Saward, 2003, p. 42; Ober, 2008, p. 3). In other words, as Reginal Basset notes, people refer to the term democracy to "cover anything and everything" they consider desirable; and, not surprisingly, some use the term to "cover anything they think undesirable" (see Pickles, 1970, p. 12). ${ }^{1}$

This denotes that interpretations and meanings attained to democracy by each scholar or perspective tacitly or overtly reflect and include some theoretical, ideological, or normative preferences. Despite their differences, these different approaches, on the other hand, might still share not only some theoretical/normative ideals or claims but also technical, practical, or institutional attributes/requirements which can be embedded in any understanding of democracy. In other words, even though democracy lacks a universally accepted meaning or institutional design of decision-making mechanism, diverse theorists could reasonably agree on some common arguments and practical issues about democracy. ${ }^{2}$

Even though the core principles and normative ideals (peace, equal participation, stability, consensus, etc.), or some institutional requirements of democracy (public political debate, voting, etc.) may be regarded as a ground for agreement among divergent perspectives, there is an ongoing disagreement over the institutions and practical implementations of democracy. Despite

\footnotetext{
${ }^{1}$ William A. Hay also argues that democracy as a term "allows for diverse meaning to suit particular objectives and the consequent lack of clarity" may cause some problems about implementing policies effectively. For further information, see Hay, 2006, p. 133.

${ }^{2}$ For an early draft of this approach, see Alkan, 2020. The author has also previously applied a similar approach to the ideal of secularism see Alkan, 2015.
} 
some commonly shared arguments and institutional dimensions, the value of particular institutional arrangements to serve democracy is not generally accepted. This has resulted in both an ongoing and growing debate over the institutional and procedural preferences in real politics to attain the values of democracy, and developing different types: direct, representative, liberal, deliberative, agonistic, etc.

As far as the aforementioned ambiguity (Schmitter and Karl, 1991, p. 75) surrounding the definition of democracy is concerned, it can be easily observed that democracy has two essential dimensions: the first of these is about the values and principles which are the intrinsic and indispensable elements of democracy, and the second is about the practical implementations of these ideals in the real world.

David Beetham (1999, p. 26), for instance, points out that there is a major antithesis in the opposition between "descriptive" and "prescriptive" conceptions of democracy. He observes that the former regards democracy as an institutional procedure while the latter regards it as a normative ideal. Democracy should be defined in the first instance in light of its "core principles" or "regulative ideals" because "any institutional definition on its own is incoherent". Nevertheless, he also stresses the importance of institutional analysis by noting that "principles on their own are barren without an understanding of the procedures through which they may be realised and the problems involved in doing so" (ibid, pp. 26-27). We may at least take from this that normative and descriptive/empirical work is distinctive and irreducible. As he purports to indicate, "there is a basic core to the meaning of democracy, which can be used to explain and resolve many of the disputed definitions and antitheses, and in respect of which the remainder can be seen to be confused or simply mistaken". In his analysis, the core principles of democracy are popular control and political equality (ibid, pp. 4-5).

In a similar vein, Bernard Brick $(2002$, p. 2) proposes that debates over the definition of democracy may be divided into the following two main categories: democracy as a set of values and as a set of institutional arrangements. The "cluster of meanings" attributed to democracy may therefore be summarised as follows: democracy as an ideal or doctrine, as a type of behaviour towards others, as certain institutional and legal arrangements, and finally as all of these together or each separately (ibid, p. 11).

In this sense, the aim of this study is not to examine all the aforementioned types of democracy in the scholarly literature following a descriptive analysis. Rather, the focus is given to exploring contestable and concurring opinions of especially late modern scholars about the concept of representation and representative democracy in the light of the aforementioned two dimensions of democracy. To narrow down the scope of analysis, the following question raised by Jonathan R. Macey (1993, p. 49) is the point of departure: "should democracy serve either to legitimize or to check government?".

According to Macey (1993, p. 49), the popular and dominant contemporary answer to this question (especially in the United States) is that democracy serves a legitimizing function. In other words, as Edward C. Banfield notes, it is the idea that today's representatives "epitomize legitimacy because they are elected representatives" and that "it is the people — the voters who rule" (see ibid, p. 51). However, Macey maintains that the Framers' (the founding fathers of the United States) vision of representative democracy should be adopted rather than the idea that democracy ought to serve a legitimatizing function (ibid, p. 53). The Framers' approach reflects the idea that "democracy serves a checking function", therefore "checking devices (judicial review, checks and balances, the separation of powers, and the executive veto)" created by representative democracy can be applied to "reduce the efficacy of majoritarianism in a democratic system" (ibid). The Framers were aware of the potential problems with the idea that the people rule. In other words, they observed the "the dangers that accompanied the rule of the 
people" and suggested establishing "a constitutional regime of checks and balances" to prevent a tyranny of the majority over minorities (ibid, p. 52).

Similarly, Rainer Knopff (1998, p. 685) also analyses James Madison's (one of the founding fathers of the United States) understanding of representative democracy which regards representative democracy as one of the significant "solution[s] to the problem of faction". As Knopff puts it, Madison's main aim was to control the damaging effects of factions because factions have a "tendency to zealotry" and all factions "are subject to what might be called the "theocratic temptation" (ibid, p. 686). After stating that factions can lead to two types of tyrannies; namely, those are "tyranny of the majority" and "tyranny of the minority" (ibid, p. 688); Madison aimed at finding "ways to offset or counteract theocratic temptation, [so to say], the fundamental source of zealous factionalism" (ibid, p. 689). Madison suggested that "separated institutions sharing powers would establish a system of check and balances" to overcome the problems associated with factionalism and to counteract different ambitions (ibid, p. 695). Even though representative democracy based on checks and balances promotes moderation in politics; "both populism and the politics of rights support extremism" (ibid, p. 702).

In this regard, in light of the aforementioned debates over the two dimensions of democracy, this study aims to answer Macey's question by examining both the concept of representation and the oft-cited definitions and understandings of representative democracy in the scholarly literature. The question of whether a consensus among divergent perspectives can be observed over the essential normative principles/values and some institutional requirements of democracy (viz. democratic legitimacy or some core checking functions) despite disagreement over the value of particular institutional arrangements to serve democracy (accountability, responsiveness, or substantive mechanisms for checking the government). This article is structured in two parts. The first part starts with an examination of the concept of representation. The second part provides the influential and oft-cited definitions and understandings of representative democracy developed especially by late modern scholars. The study is concluded with an assessment of which perspectives regard democracy as a legitimizing factor and which ones argue that it has a checking function. The concluding remarks also include a claim raised in this study that while the legitimizing function of democracy stands as a more neutral attribution embedded in and can be shared by any understanding of democracy, the checking function has a liberal content with a normative quality.

\section{The Concept of Representation}

Throughout the development of the idea of democracy, the concept has been defined in terms of "the participation of the governed in the government" (Kelsen, 1955, p. 2) directly or indirectly. Even though the first recognised form of democracy in Ancient Athens was direct democracy, representative democracy replaced it over time to some extent. Representative democracy has been the most prevalent form of democracy adopted by self-identified contemporary democracies in the late modern times and the democratic decision-making process has generally been associated with voting, elections, and particularly with majority rule.

The dominant position of representative democracy has mainly derived from the assumption that direct democracy is "unable to function efficiently in large polities" (Dalton et. al., 2001, p. 142). This is because as the size of a political unit and population grow, party politics becomes the core mechanism of decision-making (ibid). Jean-Jacques Rousseau (2014), for instance, rejected the representative form of democracy and claimed that the truest form of democracy is direct democracy. Rousseau, however, argued that the realization of true democracy is almost impossible in modern times which is characterised by geographically big political units and a high population. In a similar vein, Madison argued that "direct democracy was possible only in a small society" (Knopff, 1998, p. 688), therefore he favoured representative democracy by pointing out that assembly ought to be small while regime ought to be large (ibid, pp.691-692). 
The influential position of representative democracy can also be observed in the scholarly literature. Until a critical stance towards liberal and representative democracy is grown, the indirect democracy-oriented approaches of, i. e. Joseph A. Schumpeter (1976), Anthony Downs (1957), and Robert Dahl $(1956,1971,1982,1989)$ have been some of the influential and dominant understandings of democracy in the scholarly literature. Even though these understandings of representative democracy seem to provide a relatively neutral conception of democracy by establishing a technical and institutional framework for representative democracy, they have accepted the current conditions of politics and decision-making mechanisms in the modern era as given and put forward arguments based on some theoretical, normative, and ideological assumptions.

Before analysing their approaches; it is essential, to begin with examining the concept of representation since each definition of representation in the scholarly literature refers to and features normative or ideological preferences too. Representative democracy can be described as a model that "takes the form of party-based parliamentary rule and functions primarily through elected representatives" (Dalton et. al., 2001, p. 142). Unlike the model of direct democracy, in the representative model, the role of citizens is limited to expressing their preferences at elections, leaving policy-making to the representatives interim between election periods (ibid). This approach attains a significant role to the representatives and raises issues regarding accountability and interest realisation.

Political theorists have offered insights into the concept of representation by making several definitions of the concept and dividing it up into different types and categories. According to Albert Weale (2007, p. 132), for instance, as far as political representation is concerned, the original meaning of representation is "one thing stands for another". In a similar vein, in her oftcited classic, Hanna F. Pitkin defines representation as "the making present in some sense of something which is nevertheless not present literally or in fact" (Pitkin, 1967, p. 8). Even though the definition of the concept might itself include some normative content, the concept of representation takes several forms all of which refer to a normative choice regarding the role and function of the representatives.

Pitkin (1967) distinguishes between two types of representation: descriptive and substantive representation. Descriptive representation refers to the number or ratio of representatives elected to the political institutions who represent the various portions of the society, i.e. women, ethnic and religious minorities, ideologies, etc. Regardless of their number or ideological, ethnic, or religious background; substantive representation, on the contrary, is concerned with the effects of and active roles played by the representatives regarding interest representation in the decisionmaking and policy-making processes. In this sense, Pitkin refers to responsiveness arguing that both the representative and the represented should have autonomy, however, genuine representation occurs when the representative acts on behalf of the represented. ${ }^{3}$

In his analysis, which is based on Pitkin's aforementioned types of representation, Weale (2007, p. 133) argues that there are differences between authorization and accountability. Taking Thomas Hobbes' definition of a representative, which is "a representative is someone authorised to act for others" as a starting point, Weale claims that there is no room for accountability in Hobbes' account of understanding. In other words, emphasising authorisation concerning the idea of representation does not include the accountability of representatives towards the members of the community (ibid, p. 133). In a similar vein, Emmanuel-Joseph Sieyès (1964), for instance, argues that it is entirely legitimate for representatives elected by the people to make decisions independently of those represented. In this sense, there is a distinction between the "authorised representative" and the "accountable representative" (Weale, 2007, p. 133). In this sense, a similar

\footnotetext{
${ }^{3}$ For a similar analysis, see Anne Philips' $(1995,2002)$ distinction between the politics of ideas and the politics of presence.
} 
line between Pitkin's "substantive notion of representation" and authorised and accountable representatives can be drawn. The former, who is someone who acts in the interests of others, is quite different from the latter, because "clearly someone can act in another's interest without being authorised or accountable to that person" (ibid). Referring to Pitkin's "principle of responsiveness" Weale argues that Pitkin associates responsiveness with accountability even if they are distinct concepts. In light of the idea of party-mediated populism, Weale notes that "accountability allows elected political officials to depart from popular opinion between elections, but requires them to explain at elections how and why they behaved as they did". On the other hand, responsiveness holds that "even in the office, elected officials should implement the popular view" (ibid, p. 131). He concludes that "political representatives can be responsive to their constituents without necessarily rendering them an account or giving an explanation of their actions" (ibid, p. 133). This last argument takes us into the tension between the pluralist vision and the Burkean paradigms of the representative"s role.

After depicting the pluralist and the Burkean vision of the representative's role as competing paradigms, Macey states that the pluralist vision "considers the representative an advocate for his particular constituency". The Burkean vision, on the other hand, holds that "representatives are guardians, promoting neither their own narrow interests nor those of their constituents, but rather the broader interests of society as a whole" (ibid, p. 49). Macey regards the former paradigm as "both the dominant historical and current view" (ibid). In other words, "an inherent conflict between the private interests of a politician"s constituency and the interests of society in the aggregate" constitutes one of the basic conditions of representative democracy along with "rivalrous competition for political office" (ibid, p. 50). According to Weale (2007, pp. 140-141), the same distinction can be made between populism and Burke's approach in terms of responsiveness. Populism stresses the significance of public policy that is highly responsive to popular preferences while the Burkean approach emphasises the relative insignificance of "responsiveness to the interests and opinions of constituents".

Burke's approach, as Weale (2007, p. 141) puts it, can be regarded as an example of the elitist account that conceives political representatives as independent of their constituents and leaves no room for any element of accountability. On the other hand, by following the aforementioned argument which supports the idea that responsiveness and accountability are not identical, Burke's approach can also be regarded as reflecting the idea that "the representative is accountable but is not responsive". In other words, since "the representative owes a judgement to constituents", they can ask for such a judgement during the election process; therefore it means that (i) accountability towards electors is not necessary between elections; and (ii) representatives can behave more independently (ibid). However, no matter how his approach is read, Burke's approach can be regarded as a narrow interpretation of democracy that views elections as being at the heart of democratic politics and gives fewer roles to the people during the period between elections.

The examination of the concept of representation above shows that the relation between the representative and autonomy, authorisation, accountability, and responsiveness are complicated and open to divergent interpretations. Being a representative does not automatically mean being authorized, accountable or responsive. Moreover, according to some perspectives, a representative should not be accountable or responsive to their constituents or act solely on their particular interests. Nermin Aydemir and Rens Vliegenthart, for instance, points to a relatively dramatic exception to a common expectation: they find out that even though minority representatives are potentially expected to act on behalf of their constituency and reflect their interests in the parliaments; the representatives may support, suppress or silence cultural and/or religious freedoms. (see Aydemir and Vliegenthart, 2015). In a similar vein, in their remarkable work on the substantive representation of women, Celis and Erzeel (2015) point to a similar contradiction indicating that the presence of women representatives in parliaments or any other political institutions does not guarantee that they promote women's interests; on the contrary, 
some unusual representatives, i.e. non-feminist and male MPs, may speak out on behalf of women (see also Celis and Childs, 2012).

Given the two dimensions of democracy, the afore given analysis indicates that different perspectives on the concept of representation agree on the legitimizing and checking functions of democracy while they disagree on specific formulations of accountability or responsiveness. This conflict is much more obvious when it comes to divergent perspectives on representative democracy.

\section{Representative Democracy}

As argued in the previous section, even though the pure version of democracy was based on direct democracy, representative democracy has replaced its role over time. Representative democracy has been regarded as an "inescapable compromise in the large countries of modernity" (Knopff, 1998, p. 684) and political parties have been regarded as "inevitable" (see Pickles, 1970, p. 59) since "regularly consulting the people as a whole" is conceived practically impossible (Knopff, 1998, p. 684). Arguably there has been a tendency to identify the meaning of democracy with representative democracy in the modern era on the grounds that "under modern conditions, only representation can make democracy possible" (Pitkin, 2004, p. 336).

What are the main characteristics of representative democracy and what functions does it have? According to John Stuart Mill, representative democracy is the idea that "the whole people or some numerous portion[s] of them exercise through deputies periodically elected by themselves the ultimate controlling power" (Pickles, 1970, p. 42). In a similar vein, William A. Hay (2006, p. 136) argues that representative democracy "allows citizens to rule themselves in polities beyond the smallest communities by enabling leaders to mobilize opinion that facilitates consensus and allows them to implement policies". As far as these two selected definitions are concerned, the arguments about representative democracy cluster around the ideas of representation, competition, elections, accountability, and the scale of communities in terms of the feasibility of direct democracy. Let us have a look at the influential definitions and understandings of representative democracy in the scholarly literature.

Joseph Schumpeter's well-known definition has been one of the influential and dominant understandings of democracy throughout the twentieth century. According to Schumpeter (1976, p. 269), pre-twentieth century theories of democracy were "unrealistic" and "outdated" and are unsuitable to explain the complex, bureaucratic, and mass societies of the twentieth century. His new theory of democracy can be observed in his renowned definition: "The democratic method is that institutional arrangement for arriving at political decisions in which individuals acquire the power to decide by means of a competitive struggle for the people's vote" (ibid). It may be observed that Schumpeter's definition can be accepted as a typical example of viewing representative democracy as an institutional tool.

Schumpeter, as Saward (2003, p. 56) argues, regards democracy as a method in terms of means and seeks to "detach democracy from high-flown goals and aims" and focuses solely on the "competitive struggle for power and office". Schumpeter's political unit for democracy is the nation-state and his main concern is considering how to organise the institutional structure of central government. He views democracy as a method of selecting leaders with a special emphasis upon the representative method, and his approach mainly described what democracy is in a particular kind of political system, rather than what it ought to be (ibid, p. 56). Schumpeter associates the realm of politics with the realm of the market. The idea of competition for leadership in real politics can be compared with that of competition in the economic realm (Schumpeter, 1976, p. 271). In the game of politics, the actors combating for leadership are elites and the combat arena is elections. As for the role ordinary people play in this game, this role is not about deciding policies; instead, it is just about selecting the people who will decide policies 
on their behalf. In other words, after the people have selected a person, politics is her business and not theirs (ibid, p. 295).

Anthony Downs' "economic theory of democracy" takes a similar approach to that of Schumpeter's market-alike-game of politics. Downs nearly replicates the core assumptions of Schumpeter summarised by Saward (2003, p. 56): "the individualism, the idea of competition for office, the idea that representation is central to democracy". Similar to Schumpeter, Downs focuses on accepting the current conditions of politics as given rather than answering the question of what democracy ought to be. This reflects the aspiration to offer a value-free and descriptive account of democracy. Voters and politicians in politics as rational and competitive actors. As an individual aims to maximise her own benefits and interests by selecting the most appropriate product or service in the free market, the main role of individual voters is to select a politician or party which promises to deliver more benefit to the individual voter. The main concerns of politicians are to gain or stay in office (Downs, 1957, p. 36). In Downs' model, to stay in the office seems to require the representatives to act in line with the particular interests and benefits of the constituents.

One of the potential problems with equating politics with the games of market economy and offering a value-free conception of democracy is about the role and functions of the representatives. It is unclear in Schumpeter's and Downs' model whether assigning the role of "doing business of politics" to the representatives only means that the representatives are exempt from the duty of accountability or responsiveness. Given the similarity between politics and the market, if the quality of a product does not meet the expectations of a customer or the cost of a product is getting much higher than its benefits, the customer will most probably not buy that product again next time. Similarly, a representative should act in the interests of its constituents to be elected in the next elections. This, however, does not guarantee that the representative will act responsibly or be accountable. If the aforementioned Burkean approach is prevalent in the political system of the society, as long as checking and control mechanisms are not established, a representative can act in either her own or constituents" particular interest.

Not all the influential definitions and understandings of representative democracy in the scholarly literature provide a descriptive account of democracy, some also include basic mechanisms and institutions to check and control the risks associated with a sole constituent or politician-based interest representation. For instance, as Lon Fuller has set out the eight "principles of legality" (Fuller, 1969) to present how the current legal system's rules ought to be, Robert Dahl lists the "procedural minimal" conditions of modern political democracy to depict the required institutional guarantees for determining a system of government as democratic. Dahl's (1982, p. 11) well-known conditions can be summarised as follows: ${ }^{4}$

(i) control over government decisions about policy is constitutionally vested in elected officials; (ii) elected officials are chosen in frequent and fairly conducted elections in which coercion is comparatively uncommon; (iii) practically all adults have the right to vote in the election of officials; (iv) practically all adults have the fight to run for elective offices in the government (...); (v) citizens have a right to express themselves without the danger of severe punishment on political matters broadly defined (...) (vi) citizens have a right to seek out alternative sources of information -moreover, alternative sources of information exist and are protected by law; (vii) (...) citizens also have the right to form relatively independent associations or organizations, including independent political parties and interest groups.

It may be observed that Dahl's minimum conditions for democracy share some similar features with Schumpeter's and Downs' models. Dahl takes indirect democracy for granted, emphasises ${ }^{4}$ Dahl presents different lists in his diverse books and articles. For the list used in this study see Dahl, 1982, p. 11.
For different lists see Dahl, 1956, 1971, 1989. 
competition for power, and stresses the importance of elections and voting. However, he moves away from the descriptive account or narrow interpretation of democracy that views elections as being at the heart of democratic politics and gives no role to the people between elections (Saward, 2003 , p. 56). For this purpose, he stresses the importance of control over government decisions and develops some conditions concerning the extension of the rights of people like the freedom of expression and freedom of association. Dahl also remarkably propounds the existence and the importance of alternative sources of information protected by law. It seems Dahl means by this something to do with accountability.

Nevertheless, Dahl's aforementioned representative democracy-focused minimum conditions of democracy are significant, but not sufficient. Philippe C. Schmitter and Terry L. Karl, for instance, propose two additional conditions to complete Dahl's list of requirements for democracy. Dahl's first condition should be refined as "popularly elected officials must be able to exercise their constitutional powers without being subjected to overriding (albeit informal) opposition from unelected officials" (Schmitter and Karl, 1991, pp. 81-82). This may be accepted as a veiled attack on constitutional judicial review and it seems that they intend to call attention to one of the most controversial topics in modern democracies: the role of the military, civil servants, so to say, bureaucracy's role in democratic politics. Secondly, "the polity should be selfgoverning", put another way, "it must be able to act independently of constraints imposed by some other overarching political systems (...) [for instance] outside their territorial domain" (ibid, p. 82). Schmitter and Karl's second requirement seems to collide with the main assumptions of cosmopolitan democracy.

In a similar vein, Alfred Stepan (2000, p. 39; see also Linz and Stepan, 1996) touches upon the insufficient characteristics of Dahl's conditions and claims that they are "(...) necessary but not (...) sufficient condition[s] of democracy". They are insufficient because Dahl's conditions say nothing about "how free and fair the elections" are, or "how large the government"s majority" (Stepan, 2000, p. 39) must be, or about the idea of restricting the government by forcing it to act in line with constitutional limitations. He notes that "democracy must also have a constitution that itself is democratic in that it respects fundamental liberties and offers considerable protection for minorities". Democracy could not also be consolidated in a country unless a growing and critical civil society is helping to check the government"s actions and decisions. Similarly, Crick (2002, pp. 97-98) notes an omission in Dahl's conditions, stating that as far as the condition concerning independent political parties and interest groups is concerned, there should be a separate title regarding the "multi-party system" and "multicultural policies".

Dahl's understanding of representative democracy and critiques leveled at his approach aiming to extend his list of minimum conditions of democracy indicate that they keep defining representative democracy as a descriptively formulated institutional procedure. However, these approaches also aim to portray representative democracy as a model which has substantive or even normative qualities to promote some aims and values: checking and controlling of representatives; ensuring free elections, equal participation, freedom of expression, etc. The following recent definitions and understandings of representative democracy are the cognate examples of this tendency in the scholarly literature.

Schmitter and Karl (1991, p.79) define modern political democracy as "a system of governance in which rulers are held accountable for their actions in the public realm by citizens, acting indirectly through the competition and cooperation of their elected representatives". Similarly, Seymour M. Lipset's definition of democracy "places a heavy emphasis on elections to choose representatives that hold political office": (Bollen, 1980, p. 371). Democracy is defined "a political system which supplies regular constitutional opportunities for changing the governing officials" and also a social system that "permits the largest possible part of the population to influence major decisions by choosing among contenders for political office" (Lipset, 1963, p. 27). Pickles (1970, p. 13) also emphasises the indirect type of democracy and views democracy 
as "a set of institutions" which accomplish two main requirements: (i) it must be able to "elicit as accurately as possible the opinion of as many people as possible on who shall be their representatives and on how the country ought to be governed"; (ii) "it must provide ways of ensuring that those chosen by the public do in fact do what the electorate wants them to do or that they can be replaced if they do not, even between elections". Gerhard E. Lenski (1966, p. 319), from a different perspective, states that democratic political systems cannot only be identified with the electoral franchise; rather, they should also be associated with the existence of political liberties. Like Lenski, Ho-Won Jeong (2005, p. 114) posits that elections are not identical with democracy, and democracy cannot be reduced to elections, without obtaining established rules by all players.

\section{CONCLUSION AND EVALUATION}

The chief focus in this study has been laid on examining divergent definitions and understandings of the concept of representation and the representative democracy developed by some influential late modern scholars in academia. For this purpose, firstly, the concept of representation itself, different types thereof, their relationship, and tension with authorisation, accountability, and responsiveness are analysed. Secondly, the meanings of representative democracy offered by some influential scholars have been canvassed by drawing distinctions between and clarifying different claims about it with reference to a claim and a question: (i) democracy has two dimensions, namely, normative and institutional dimensions, and (ii) should democracy legitimize or check the government?

Democracy has two dimensions. While the normative dimension views democracy as a normative ideal with inherent values that needed to be ensured and promoted, the institutional dimension views democracy as an institutional procedure with particular institutional arrangements that are formulated to serve democracy. There may be disagreement over the value of particular institutional arrangements to serve democracy, however, there is a prevailing consensus over the essential normative principles or values and some institutional requirements of democracy.

Given the main focus of this study and Macey's question, the aforementioned ground for agreement among the examined different perspectives on representation and representative democracy is the principle of democratic legitimacy. They all take democratic legitimacy or the cognate and interrelated principles of popular consent and the rule by the people, ${ }^{5}$ for granted. Any definition or perspective on the concept of representation or representative democracy must naturally refer to the ideal of democratic legitimacy, because, as Kelsen $(1955$, p. 3) rightly argues, "no answer whatsoever justifies rejecting the concept of democracy as government by the people and replacing it by another concept (...)". Democratic legitimacy via elected representatives is one of the core principles among many other "generic concepts" that distinguish representative democracy "as a unique system for organising relations between rulers and the ruled" (see Schmitter and Karl, 1991, p. 76). Any understanding of representation or representative democracy accepts the popular power or popular sovereignty as the source and justification of political authority. There is a consistency of viewing that democracy serves as a legitimizing function within the afore-examined influential conceptions of representative democracy in the scholarly literature.

Even though different perspectives on representative democracy agree on democracy's legitimizing function, they disagree on accountability or responsiveness of representatives or the minimum conditions of representative democracy. Debates over accountability or guarantees for a more genuine and inclusive representative democracy refer not only to the legitimizing but also to the checking function. Being a legitimate elected representative or government does not always

\footnotetext{
${ }^{5}$ It should be pointed out there is a distinction between rule and participation. Participation of the people does not directly result in rule by the people. For instance, regular elections can be arranged under the rule of an authoritarian leader or a nondemocratic government.
} 
guarantee that they act or develop public policies in line with democratic principles and values. A democratic political regime might potentially turn into a tyranny of the majority unless checking and controlling mechanisms are created. Even though the examined perspectives on representative democracy share some core checking mechanisms, viz. control over government decisions, ensuring free and fair elections, the freedom of expression, and the freedom of association, conflict becomes much more obvious when it comes to envisioning more substantive values or institutional mechanisms.

This is because while legitimizing function of democracy stands as a more neutral attribution embedded in and can be shared by any understanding of (representative) democracy, the checking function has a liberal content with a normative quality. Liberalism limits the power of the state, separates the legislative, executive, and judicial powers, and creates mechanisms for checking the government with a view to ensuring a substantive ideal: to protect individual liberty. The individual is seen as inherently valuable in liberal theory. The individual should act only by her own personal interest and pursuit happiness without aiming to realize a certain social good. This is guaranteed only when liberty is defined in negative terms, the public and the private spheres are distinguished, a constitutional political regime based on the separation of powers and the rule of law is established.

Answering the questions of any democracy should serve as a checking function or any democracy without a liberal content cannot be a genuine democracy can be a subject of another comprehensive study. This study can therefore provide ground for further research on the relationship between liberalism and democracy.

\section{REFERENCES}

Alkan, Y. S. (2015). Facilitative Secularism: The Place of Religious Arguments in Public Political Debate (Unpublished Ph.D. Thesis). The University of Leicester.

Alkan, Y. S. (2020). Demokrasi ve Siyasal Katılımın Değeri: Doğrudan ve Temsili Demokrasi Üzerine Güncel Tartışmalar [Democracy and the Value of Political Participation: Recent Debates on Direct and Representative Democracy]. In T. Şener (Ed.), Siyaset, Medya ve Seçmen [Politics, Media, and Elector] (ss. 31-44). Ankara: Nobel Bilimsel Eserler.

Anderson, C. D. and Stephenson, L. B. (2020). What is Democracy and How Do We Study It? Toronto, Buffalo and London: Toronto University Press.

Aydemir, N. and Vliegenthart, R. (2015). "Minority Representatives" in the Netherlands: Supporting, Silencing or Suppressing? Parliamentary Affairs, 69(1), 1-20.

Beetham, D. (1999). Democracy and Human Rights. Cambridge: Polity Press.

Bollen, K. A. (1980). Issues in the Comparative Measurement of Political Democracy. American Sociological Review, 45(3), 370-390.

Celis, K. and Childs, S. (2012). The Substantive Representation of Women: What to Do with Conservative Claims? Political Studies, 60(1), 213-225.

Celis, K. and Erzeel, S. (2015). Beyond the Usual Suspects: Non-Left, Male and Non-Feminist MPs and the Substantive Representation of Women. Government and Opposition, 50(1), 45-64.

Collins, H., Evans, R., Durant, D. and Weinel, M. (2020). What Is Democracy? In Experts and the Will of the People: Society, Populism and Science (pp. 23-34). Cham: Palgrave.

Crick, B. (2002). Democracy: A Very Short Introduction. New York: Oxford University Press. 
Dahl, R. A. (1956). A Preface to Democratic Theory. Chicago: University of Chicago Press.

Dahl, R. A. (1971). Polyarchy: Participation and Opposition. New Haven: Yale University Press.

Dahl, R. A. (1982). Dilemmas of Pluralist Democracy. New Haven: Yale University Press.

Dahl, R. A. (1989). Democracy and its Critiques. New Haven: Yale University Press.

Dalton, R. J., Burklin W. P. and Drummond, A. (2001). Public Opinion and Direct Democracy. Journal of Democracy, 12(4), 141-153.

de Schweinitz, K. (1964). Industrialization and Democracy. New York: Free Press.

Diamond, L. J. (1990). Three Paradoxes of Democracy. Journal of Democracy, 1(3), 48-60.

Downs, A. (1957). An Economic Theory of Democracy. New York: Harper and Row.

Fuller, L. L. (1969). The Morality of Law. New Haven, Conn.: Yale University Press.

Gagnon, J. P. (2009). The Element of Democracy: A Theory and Definition of Democracy Implications for the MDGs. Meeting the Millennium Development Goals: Old Problems, New Challenges Conference, Melbourne, 30 November - 1 December 2009. https://iuristebi.files.wordpress.com/2012/12/the-element-of-democracy-a-theory-anddefinition-of-democracy.pdf

Hay, W. A. (2006). What is Democracy? Liberal Institutions and Stability in Changing Societies. Orbis, 50(1), 133-151.

Held, D. (2006). Models of Democracy. Cambridge and Malden: Polity.

Jeong, H. W. (2005). Peacebuilding in Postconflict Societies: Strategy and Process. Boulder, Co.: Lynne Rienner Publishers.

Kelsen, H. (1955). Foundations of Democracy. Ethics, 66(1), 1-101.

Knopff, R. (1998). Populism and the Politics of Rights: The Dual Attack on Representative Democracy. Canadian Journal of Political Science, 31(4), 683-705.

Lenski, G. (1966). Power and Privilege: A Theory of Social Stratification. Chapel Hill and London: The University of North Carolina Press.

Linz, J. J. and Stepan, A. C. (1996). Problems of Democratic Transition and Consolidation: Southern Europe, South America and Post-Communist Europe. Baltimore, M. D.: The Johns Hopkins University Press.

Lipset, S. M. (1963). Political Man. New York: Anchor Books.

Macey, J. (1993). Representative Democracy. Harvard Journal of Law, 16(1), 49-54.

Ober, J. (2008). The Original Meaning of "Democracy": Capacity to Do Things, Not Majority Rule. Constellations, 15(1), 3-9.

Paul, E. F., Miller, F. D. and Paul, J. (Eds.) (2000). Democracy. Cambridge: Cambridge University Press.

Phillips, A. (1995). The Politics of Presence. Oxford: Clarendon Press.

Phillips, A. (2012). Representation and Inclusion. Politics \& Gender, 8(4), 512-518.

Pickles, D. (1970). Democracy. London: BT Batsford Ltd.

Pitkin, H. F. (1967). The Concept of Representation. Berkeley: University Of California Press.

Pitkin, H. F. (2004). Representation and Democracy: Uneasy Alliance. Scandinavian Political Studies, 27(3), 335-342.

Ringen, S. (2007). What Democracy is for. Princeton, N. J.: Princeton University Press. 
Roskin, M. G., Cord, R. L., Medeiros, J. A., and Jones, W. S. (2003). Political Science: An Introduction. Essex: Prentice-Hall.

Rousseau, J. J. (2014) [1762]. The Social Contract, tr. G. D. H. Cole. Scotts Valley, CA: CreateSpace Independent Publishing Platform.

Saward, M. (2003). Democracy. Cambridge: Polity Press 2003.

Schmitter, P. C. and Karl, T. L. (1991). What Democracy is... and is not. Journal of Democracy, 2(3), 75-88.

Schumpeter, J. A. (1976). Capitalism, Socialism and Democracy. London: Allen and Unwin.

Stepan, A. C. (2000). Religion, Democracy, and the "Twin Tolerations". Journal of Democracy, 11(4), 37-57.

Sieyès, E. J. (1964) [1789]. What is the Third Estate? New York: Praeger.

Weale, A. (2007). Democracy. Basingstoke: Palgrave Macmillan. 